\title{
BOTTOM SEDIMENTS AS AN ELEMENT OF THE KRĄPIEL RIVER ECOSYSTEM
}

\author{
Małgorzata Raczyńska', Sylwia Machula², Paweł Łukaszewicz², Mariusz Raczyński
}

1 West Pomeranian Technological University in Szczecin, Department of Marine Ecology and Environmental Protection, Piastów 17 Av., 70-310 Szczecin, Poland, e-mail: malgorzata.raczynska@zut.edu.pl

2 West Pomeranian University of Technology, Department of Hydrochemistry and Aquatic Biological Resources, Piastów 17 Av., 70-310 Szczecin, Poland, e-mail: sylwia.machula@zut.edu.pl

${ }^{3}$ West Pomeranian University of Technology, Department of Fisheries Management, Piastów 17 Av., 70-310 Szczecin, Poland, e-mail: mariusz.raczynski@zut.edu.pl

Received: 2015.12.22

Accepted: 2016.03.04

Published: 2016.04.01

\begin{abstract}
Research on the structure of sediments was carried out in 2015 in the river Krapiel and its tributaries. The main objectives of this study were to classify the types of sediments with grain size analyzing according three different criteria, as well as influence of the substrate on the abundance and diversity of macrobenthic organisms, and to determine the quality of the ground for natural breeding of salmonids. It was found that according to Polish standards, bottom sediments of the Krapiel river and its tributaries belong to the coarse - gravel type or sandy - gravel type, whereas according to the method used in Anglo-Saxon countries - these are sandy sediments. It was also shown that the grain size of bottom sediments of the Krapiel river and its tributaries determine friendly living environment for macroinvertebrates and for breeding salmonids.
\end{abstract}

Keywords: bottom sediments, Krapiel river, breeding of salmonids, bottom fauna.

\section{INTRODUCTION}

Substrate is a complex element of the physical environment of running waters and although it is not the only factor playing a decisive role in the distribution of living organisms, there is no doubt that its importance should not be underestimated. Morphological conditions of watercourses, and especially the structure and quality of substrate largely determine biological features, such as spatial and quantitative species structure [Allan 1998]. A varied range of substrate types can be observed along almost every single river stretch, and no substrate is entirely homogenous. Substrates in running water habitats affect the distribution and abundance of living organisms, so they also determine natural reproduction of salmonids. Substrate sediments may be classified according to various criteria: granulometric composition (particle size), origin of substances of which sediment is composed of, environmental features of the location where the sediment has accumulated, sedimentation and the age of accumulated sediment. A simple classification method is to determine granulometric composition of bottom sediment according to grain and particle sizes. Then, on the basis of the obtained data it is possible to specify the fauna characteristic of a given substrate type and evaluate a potential suitability of a given river stretch for fish reproduction. In the case of monitoring studies, river bottom structure is determined on the basis of observations and bottom sediment fractions are identified without the necessity to conduct laboratory analyses. For instance, this was the case in Poland while monitoring microbenthic invertebrates [Bis and Mikulec 2013]: at the time of sample collection, in the field protocol for the multihabitat sampling (MHS), the type of river habitat is identified according to the mineral habi- 
tat classification, similar to the classification used while studying soil types. However, this method of classification has certain drawbacks. Roughly determined percentages of individual fractions are encumbered with a considerable error, especially in the case of deep rivers or watercourses whose waters are opaque or muddy. In the case of a muddy river, its bottom is composed mainly of sand and gravel [Allan 1998], which may render determining habitat types difficult. Those difficulties may be avoided by determining sediment particles sizes by sieving and then comparing the results against a sediment particle size scale specified by official standards. In Poland, in the years 1986-2006, soil (sediment) classification according to PN-B-02480:1986 standard was in force. Presently, international standards developed by CEN (Comité Européen de Normalisation) are binding. The CEN standards were translated into Polish in 2006 and they came into force in June that year (PN-EN ISO 14688-1:2006 and PN-EN ISO 14688-2:2006 standards). Meanwhile, in many Anglo-Saxon countries sediment grain sizes are determined according to Wentworth grain size classification [Allan 1998 after Cummins 1962, Minshall 1984, Blott and Kenneth 2001]. For the purposes of the present study, both of the above sediment classification methods have been applied and compared.

\section{MATERIAL AND METHODS}

\section{Study area}

The Krąpiel river, running across the Western Pomeranian voivodeship, Stargard poviat, is the largest right tributary of the Ina river and is $60 \mathrm{~km}$ long. It has its source in Starzyc lake near Cho- ciwel at the altitude of 68 m.a.s.l., and joins the Ina river near Stargard at 21 m.a.s.l. Its drainage basin is $640.2 \mathrm{~km}^{2}$. It collects water from mostly agricultural land. Along its whole length, the Krapiel river meanders picturesquely. The mouth of the river, due to its environmental and landscape value, belongs to Natura 2000 network, listed as a Special Habitat Protection Area "Dolina Krąpieli" (PLH320005). Almost along the whole length of the river, the Krapiel valley is covered with deciduous forests. A steep slope of the river affects the shape of the river bed as well as the landscape of the whole valley and determines the presence of animal and plant species, typical for foothill areas, which is especially noticeable along the stretch between Pęzino and Strachocin. The Krapiel valley includes localities of some freshwater flora species that are on the verge of extinction, not only in Pomerania but everywhere in Poland, i.a. Corydalis cava and Corydalis intermedia, as well as Corydalis pumila, included in the Polish Red Data Book of Plants. Hildebrandia rivularis, a red alga species responsible for the presence of characteristic bright red patches on stones was encountered in the river itself, as well as other rare species of encrusting red algae. Tributaries of the Krąpiel include i.a. the Pęzinka river and the Krępa river. The Krępa is a $27 \mathrm{~km}$ long, right tributary with a source in the Okonie lake and a drainage basin of $157 \mathrm{~km}^{2}$. The Pęzinka is a $28 \mathrm{~km}$ long, left tributary with a drainage ba$\sin$ of $91 \mathrm{~km}^{2}$ [Złoczowska et al. 2008, Raczyńska and Machula 2006 after Chełkowski and Filipiak 1988, Keszka et al. 2013].

Material for studying bottom sediments of the Krapiel river and its tributaries was collected from 6 sites located within its middle and lower reaches (Figure 1):

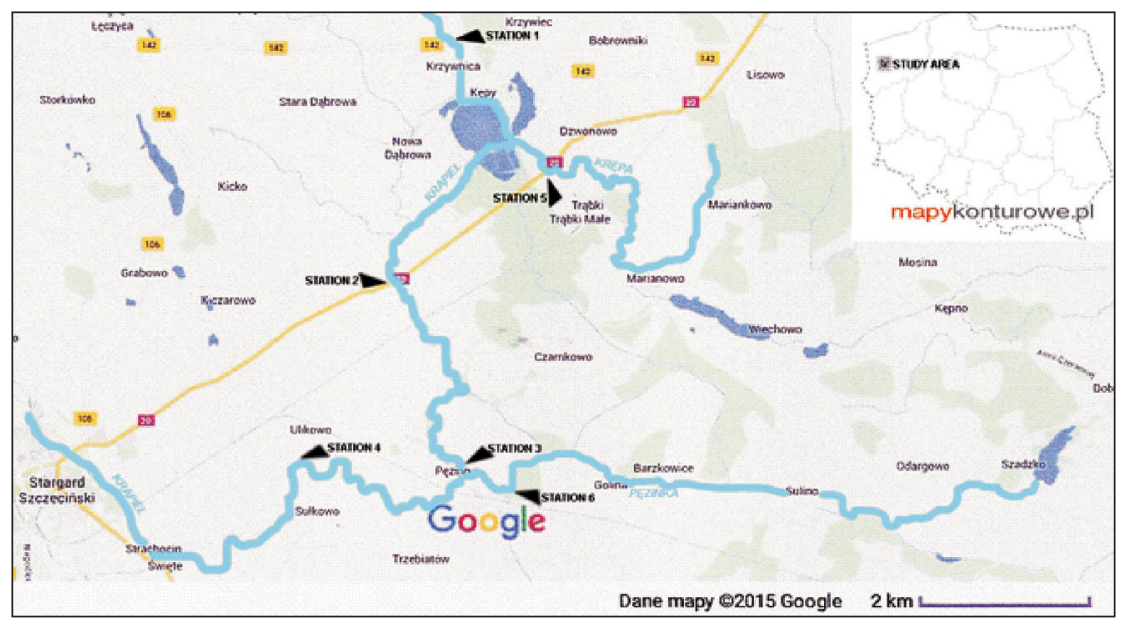

Figure 1. Location of sampling sites 
- Site 1 - the Krąpiel river - Rokicie-Krzywnica by the regional road no. 142

- Site 2 - the Krąpiel river - Dalewo-Gogolewo

- Site 3 - the Krąpiel river - Pęzino

- Site 4 - the Krąpiel river - Ulikowo-Sułkowo

- Site 5 - the Krępa river - Modehpolmo

- Site 6 - the Pęzinka river - upstream from Pęzino

Granulometric composition of bottom sediments collected from the above sites was determined by sieving method according to current standards [PN-B-02480:1986, PN-EN ISO 14688:2006]. Then, percentages of individual bottom sediment fractions $\left(\mathrm{Z}_{\mathrm{i}}\right)$ were calculated using the following equation:

$$
Z_{i}=\frac{m_{i}}{m_{s}} \times 100 \%
$$

where: $m_{i}-$ mass of fraction retained on the sieve $[\mathrm{g}]$,

$$
m_{s} \text { - mass of the sieved sample [g]. }
$$

Results of the bottom sediment analysis were displayed graphically by a cumulative curve showing the percentage of sediment mass sieved through each sieve (so-called granulation curve). Then, using granulation curve graphs, percentages of individual sediment fractions were determined, as required for soil type (sediment type) identification. On the basis of percentages of individual fractions, soil (bottom sediment) was classified according to PN-B-02480:1986 and PN-EN ISO 14688 standards, and according to Wentworth's phi $(\varphi)$ scale.

\section{RESULTS}

\section{Sediment fractions according to PN-B-02480:1986 standard}

In all sites in the Krapiel river and its tributaries only two bottom sediment fractions were encountered: gravel (particle diameter from 2.0 to $40 \mathrm{~mm}$ ) and coarse sand (particle diameter from 0.5 to $2.0 \mathrm{~mm}$ ); their percentages differed from one site to another (Table 1). As the gravel fraction prevailed in all sites in the Krąpiel river and its tributaries, the bottom sediment type was classified as coarse sediment - gravel (Ż) (Table 2).

\section{Sediment fractions according to PN-EN ISO 14688-2 standard}

In all sites in the Krapiel river and its tributaries only two bottom sediment fractions were encountered: gravel (particle diameter from 2.0 to $40 \mathrm{~mm}$ ) and sand, with only its coarse fraction present (particle diameter from 0.5 to $2.0 \mathrm{~mm}$ ). Percentages of those fractions were different in

Table 1. Bottom sediment fractions in the individual sites in the Krąpiel river and its tributaries according to PN-

\begin{tabular}{|c|c|c|c|c|c|c|c|c|}
\hline \multirow{2}{*}{\multicolumn{2}{|c|}{ Fraction by $\mathrm{PN}-86 / \mathrm{B}-0248$}} & \multirow{2}{*}{ Cobbles } & \multirow{2}{*}{ Gravel } & \multicolumn{3}{|c|}{ Sand $0.05<d \leq 2.0$} & \multirow{2}{*}{ Silt } & \multirow{2}{*}{ Clay } \\
\hline & & & & coarse sand & medium sand & fine sand & & \\
\hline \multicolumn{2}{|c|}{ Diameter [mm] } & $d>40$ & $2.0<d \leq 40$ & $0.5<\mathrm{d} \leq 2.0$ & $0.25<d \leq 0.5$ & $0.05<d \leq 0.25$ & $0.002<d \leq 0.05$ & $\leq 0.002$ \\
\hline \multirow{6}{*}{$\begin{array}{l}\text { Percentage } \\
\quad[\%]\end{array}$} & site 1 & & 50.50 & 49.50 & & & & \\
\hline & site 2 & & 79.25 & 20.75 & & & & \\
\hline & site 3 & & 83.75 & 16.25 & & & & \\
\hline & site 4 & & 99.00 & 1.00 & & & & \\
\hline & site 5 & & 99.00 & 1.00 & & & & \\
\hline & site 6 & & 93.75 & 6.25 & & & & \\
\hline
\end{tabular}
B-02480:1986 standard

\begin{tabular}{|c|c|c|c|}
\hline \multirow{2}{*}{ Site } & PN-B-02480:1986 & PN-EN ISO 14688:2006 & Wentworth (1922) \\
\hline & \multicolumn{3}{|c|}{ Substrate types } \\
\hline $\begin{array}{l}\text { 1. Krąpiel - Rokicie-Krzywnica - by } \\
\text { road } 142\end{array}$ & coarse sediment - gravel & coarse sediment - sandy gravel & gravel - medium gravel \\
\hline 2. Krąpiel - Dalewo-Gogolewo & coarse sediment - gravel & coarse sediment - sandy gravel & sand - fine sand \\
\hline 3. Krąpiel - Pęzino & coarse sediment - gravel & coarse sediment - gravel & sand - medium sand \\
\hline 4. Krąpiel - Ulikowo-Sułkowo & coarse sediment - gravel & coarse sediment - gravel & sand - fine sand \\
\hline 5. Krępa - Modehpolmo & coarse sediment - gravel & coarse sediment - gravel & sand - fine sand \\
\hline 6. Pęzinka - powyżej Pęzina & coarse sediment - gravel & coarse sediment - gravel & sand - medium sand \\
\hline
\end{tabular}

Table 2. Substrate types in the Krapiel river and its tributaries according to different classifications 
different sites (Table 3). According to percentages of individual fractions in the Krapiel river, sediments in sites 1 and 2 were classified as coarse sediments, i.e. sandy gravel (saGr), and in the remaining sites located in the Krąpiel river, as well as those in the Krępa, and in the Pęzinka, sediments were classified as coarse sediment - gravel (Gr) (Table 3).

\section{Sediment fractions according to Wentworth (1922)}

In all sites in the Krąpiel river and its tributaries three bottom sediment fractions were identified: gravel (particle diameter from 2.0 to $16 \mathrm{~mm}$ ), sand (particle diameter from 0.063 to $1.0 \mathrm{~mm}$ ) and muddy clay (particle diameter smaller than $0.063 \mathrm{~mm}$ ). Their percentages varied among sites. It ought to be highlighted that within the sand fraction all types of sand were encountered, i.e. very coarse, coarse, medium, fine and very fine sand (Table 4). On the basis of fractions prevailing in particular sites, the following bottom sediment types were identified: gravel - medium gravel in only one site (the Krąpiel river, site 1), and sandy sediments in the remaining sites. Fine sand was encountered in the Krąpiel river (sites 2 and 4) and in the Krępa river, while medium sand was encountered in the Krąpiel river (site 3) and in the Pęzinka river (Table 4).

\section{DISCUSSION}

Substrate is a complex element of the physical environment of running waters and even though it is not the only factor determining the distribution of living organisms, there is no doubt about its crucial importance. Substrates associated with running waters are diversified, displaying both vertical and horizontal heterogeneity and a tendency to change over time and depending on flow rate. Two basic substrate types can be distinguished: organic and inorganic ones. Inorganic substrate is composed mainly of mineral particles that can be arranged according to size, from loam and clay to boulders, and is the ground for aquatic fauna. Meanwhile, organic substrate is composed

Table 3. Bottom sediment fractions in the individual sites in the Krapiel river and its tributaries according to PNEN ISO 14688:2006 standard

\begin{tabular}{|c|c|c|c|c|c|c|c|c|c|c|c|c|c|c|}
\hline \multirow{2}{*}{\multicolumn{2}{|c|}{$\begin{array}{c}\text { Fraction by PN-EN } \\
\text { ISO 14688-2 }\end{array}$}} & \multirow{2}{*}{ Boulders } & \multirow{2}{*}{ Stones } & \multirow{2}{*}{ Cobbles } & \multicolumn{3}{|c|}{$\begin{array}{c}\text { Gravel } \\
2.0<d \leq 63\end{array}$} & \multicolumn{3}{|c|}{$\begin{array}{c}\text { Sand } \\
0.063<d \leq 2.0\end{array}$} & \multicolumn{3}{|c|}{$\begin{array}{c}\text { Silt } \\
0.002<d \leq 0.06\end{array}$} & \multirow{2}{*}{ Clay } \\
\hline & & & & & $\begin{array}{l}\text { coarse } \\
\text { gravel }\end{array}$ & \begin{tabular}{|c|} 
medium \\
gravel
\end{tabular} & $\begin{array}{l}\text { fine } \\
\text { gravel }\end{array}$ & $\begin{array}{l}\text { coarse } \\
\text { sand }\end{array}$ & $\begin{array}{l}\text { medium } \\
\text { sand }\end{array}$ & $\begin{array}{l}\text { fine } \\
\text { sand }\end{array}$ & $\begin{array}{c}\text { coarse } \\
\text { silt }\end{array}$ & $\begin{array}{l}\text { medium } \\
\text { silt }\end{array}$ & fine silt & \\
\hline \multicolumn{2}{|c|}{ Diameter [mm] } & $>630$ & $200<d \leq 630$ & $63<d \leq 200$ & $20<d \leq 63$ & $6.3<d \leq 20$ & $2.0<d \leq 6.3$ & $\begin{array}{c}0.63<\mathrm{d} \\
\leq 2.0\end{array}$ & $\begin{array}{l}0.2<d \\
\leq 0.63\end{array}$ & $\begin{array}{c}0.063<\mathrm{d} \\
\leq 2.0\end{array}$ & $\begin{array}{l}0.02<d \\
\leq 0.063\end{array}$ & $\begin{array}{c}0.0063<d \\
\leq 0.02\end{array}$ & $\begin{array}{l}0.002<d \\
\leq 0.0063\end{array}$ & $d \leq 0.002$ \\
\hline \multirow{6}{*}{$\begin{array}{c}\text { Percentage } \\
{[\%]}\end{array}$} & site 1 & & & & & 10 & 40.5 & 49.5 & & & & & & \\
\hline & site 2 & & & & & 39.85 & 39.40 & 20.75 & & & & & & \\
\hline & site 3 & & & & & 7.50 & 76.25 & 16.25 & & & & & & \\
\hline & site 4 & & & & & 70.00 & 29.00 & 1.00 & & & & & & \\
\hline & site 5 & & & & & 91.25 & 7.75 & 1.00 & & & & & & \\
\hline & site 6 & & & & & 17.50 & 76.25 & 6.25 & & & & & & \\
\hline
\end{tabular}

Table 4. Bottom sediment fractions in the individual sites in the Krąpiel river and its tributaries according to Wentwortha scale

\begin{tabular}{|c|c|c|c|c|c|c|c|c|c|c|c|c|c|c|c|}
\hline \multirow{2}{*}{\multicolumn{2}{|c|}{$\begin{array}{c}\text { Fraction by } \\
\text { Wentworth (1922) }\end{array}$}} & \multirow[b]{2}{*}{ Boulders } & \multicolumn{2}{|c|}{$\begin{array}{c}\text { Stones } \\
64<d \leq 256\end{array}$} & \multicolumn{2}{|c|}{$\begin{array}{c}\text { Cobbles } \\
16<d \leq 64\end{array}$} & \multicolumn{3}{|c|}{$\begin{array}{c}\text { Gravel } \\
2.0<d \leq 16\end{array}$} & \multicolumn{5}{|c|}{$\begin{array}{c}\text { Sand } \\
0.063<d \leq 1.0\end{array}$} & \multirow[b]{2}{*}{ Silt/clay } \\
\hline & & & large & small & large & small & $\begin{array}{l}\text { coarse } \\
\text { gravel }\end{array}$ & $\begin{array}{c}\text { medium } \\
\text { gravel }\end{array}$ & $\begin{array}{c}\text { fine } \\
\text { gravel }\end{array}$ & $\begin{array}{c}\text { very } \\
\text { coarse } \\
\text { sand }\end{array}$ & $\begin{array}{c}\text { coarse } \\
\text { sand }\end{array}$ & $\begin{array}{l}\text { medium } \\
\text { sand }\end{array}$ & $\begin{array}{l}\text { fine } \\
\text { sand }\end{array}$ & $\begin{array}{c}\text { very fine } \\
\text { sand }\end{array}$ & \\
\hline \multicolumn{2}{|c|}{ Diameter [mm] } & $>256$ & $128<d \leq 256$ & $64<d \leq 128$ & $32<d \leq 64$ & $16<d \leq 32$ & $8<d \leq 16$ & $4<d \leq 8$ & $2<d \leq 4$ & $1<d \leq 2.0$ & $\begin{array}{l}0.5<\mathrm{d} \\
\leq 1.0\end{array}$ & $\begin{array}{c}0.25<d \\
\leq 0.5\end{array}$ & $\begin{array}{c}0.125<d \\
\leq 0.25\end{array}$ & $\begin{array}{l}0.063<d \\
\leq 0.125\end{array}$ & $d \leq 0.063$ \\
\hline \multirow{6}{*}{$\begin{array}{c}\text { Percentage } \\
{[\%]}\end{array}$} & site 1 & & & & & & & 43.75 & 13.75 & 5.00 & 10.00 & 16.25 & 6.25 & 2.50 & 2.50 \\
\hline & site 2 & & & & & & & 10.00 & 10.00 & 11.25 & 10.00 & 10.00 & 26.25 & 20.00 & 2.50 \\
\hline & site 3 & & & & & & & 15.00 & 15.00 & 12.50 & 22.50 & 23.75 & 7.50 & 2.50 & 1.25 \\
\hline & site 4 & & & & & & & & 1.25 & 3.75 & 4.25 & 15.00 & 60.75 & 13.75 & 1.25 \\
\hline & \begin{tabular}{|l|} 
site 5 \\
\end{tabular} & & & & & & & & 1.25 & 1.25 & 0.50 & 3.75 & 42.50 & 47.00 & 3.75 \\
\hline & site 6 & & & & & & & 5.00 & 1.25 & 2.50 & 15.00 & 53.75 & 16.25 & 5.00 & 1.25 \\
\hline
\end{tabular}


of organic particles (smaller than $1 \mathrm{~mm}$ ) and consists mainly of fallen leaves, sunken wood, moss and plant fragments, which usually serve aquatic animals as food. The type of inorganic substrate depends largely on the type of its bedrock, but there is a general tendency for diameters of bedload particles to decrease along the river course. In many mountainous regions river bottoms are composed of stones and pebbles, while in lowland areas the bottoms are sandy. Even muddy rivers are characterised by substrates composed mainly of sand and gravel, while muddy bottoms are rare [Allan 1998]. According to the findings of the present study, bottom sediments of the Krąpiel river and its tributaries are composed mainly of gravel and sand (Tables 1-4), which indicates the lowland character of the studied rivers. Granulometry of those sediments was studied by Brysiewicz et al. [2012] and Keszka et al. [2013]. The latter author obtained slightly different results from those obtained in the present study. In the Krąpiel river near Ulików, Brysiewicz et al. [2012] classified the substrate as coarse gravel, whereas according to Keszka et al. [2013] it was mostly sandy. On the other hand, Brysiewicz et al. [2012] classified bottom sediment in the Pęzinka river near Pęzin as gravel, whereas by Keszka et al. [2013] it was classified as sand, the same as in the present study, according to one of the applied methods of classifying bottom sediments. According to Polish Standard of 1986 and of 2006, sediment in that site was classified as gravel, while according to Wentworth scale, it was classified as sand (Table 2). Then, which of the two classifications was objective? It seems that the classification based on Polish standards and the results obtained by Brysiewicz et al. [2013] were objective, because in both cases the equivalent grain diameters in gravel fractions were similar. Meanwhile, the classification proposed by Keszka et al. [2013] was based on bottom observations conducted as part of bonitation studies and was based on a subjective evaluation.

Diversity and abundance of organisms increase together with increasing substrate stability and detritus presence, which indirectly depends on average sizes and size diversification of mineral particles, as well as on substrate structure [Allan 1998]. Sediment type also plays a role in how living organisms benefit from their sedimentary habitat and how species in that habitat interact. Some aquatic invertebrates show clear preferences regarding substrate types. The least favourable environment for macroinvertebrates associated with the river bottom is sand, mainly due to its lack of stability and its low detritus retention caused by considerable grain compactness that reduces oxygen availability. Representatives of aquatic invertebrates associated with the sandy bottom are mainly larvae of chironomids and the oligochaetes [Allan 1998, Kownacki and Soszka 2004]. However, European rivers are also inhabited by psammophilous species of the Ephemeroptera larvae, for which a sandy substrate is an ideal habitat. Still, those species can rather be encountered in large lowland rivers, as sandy bottoms of small rivers are not rich enough to allow for the development of their communities. Burrowing mayfly larvae, e.g. of the genus Ephemera, which burrow in gravel substrate, can be more frequently encountered in smaller rivers [Głazaczow 1999]. Meanwhile, freshwater clams of the genus $\mathrm{Pi}$ sidium are more likely to dominate on the sandy bottom, which is justified by their biology. The most abundant populations of those clams in Poland have been encountered in small watercourses with bottoms composed of fine sand and loess sediments [Piechocki 1986, 1992, Włosik-Bieńczak 1992, Czerniawska-Kusza 2001, Raczyńska et al. 2010]. The number and density of bottom fauna species are the highest on coarse inorganic substrates (gravel and cobbles) and on mosses, and differ depending on detritus availability [Allan 1998]. However, that kind of inorganic substrate is conducive to the development of a high diversity of fauna, as has been noted by a number of authors [Kownacki et al. 2004, Rybak and Umińska-Wasiluk 2007, Czerniawska-Kusza and Szoszkiewicz 2007, Lampart-Kałużniacka and Śliwińska 2011]. On a gravel substrate (particle sizes from 2 to $16 \mathrm{mmm}$ ), typical representatives of macrobenthic fauna, classified as psephophilous fauna include the Ephemeroptera (Ephemera danica), Plecoptera (genus Chloroperla), Trichoptera, and the Chironomidae, whereas on a cobbly bottom typical representatives of litophilous fauna are the Ephemeroptera (families Heptageniidae and Baetidae), Plecoptera, Trichoptera (genus Silo), and the Diptera (families Simuliidae and Blephariceridae) [Kownacki and Soszka 2004]. According to a study by Raczyńska et al. [2012a, b], the invertebrate fauna of the Krapiel river is dominated by insects (with caddisflies being the most abundant), which would indicate the pres- 
ence of a fauna typical for gravel substrate. Not only do invertebrates require a specific substrate type during their life cycle. Many fish species swimming during the breeding season require a substrate providing specific conditions for a certain period of time after spawning. Most freshwater fish species choose a hard surface for spawning, ranging from individual stones to gravel. An advantage of a coarse, mineral substrate is that it facilitates building nests, where roe and milt can mix and are not washed out by running water. Apart from that, water can enter crevices within a coarse substrate and thus abundant amounts of oxygen can reach the roe hidden in that substrate [Allan 1998]. Therefore, coarse bottom sediments of the Krapiel river and its tributaries (Table 2) are, theoretically, an ideal place for the presence and natural reproduction of salmonids. In practice, the situation may be more complicated because determining the usefulness of running waters for salmonids requires that not only the optimal character of substrate is taken into account, but also physical and chemical water parameters. Studies of water in the Krąpiel river conducted by Raczyńska and Machula [2006] revealed that such parameters as dissolved oxygen, nitrites, total phosphorus, $\mathrm{BOD}_{5}$ and total suspended solids did not meet standards required by salmonids. Studies conducted over a stretch of the Krapiel river and its tributaries by Brysiewicz et al. [2012] revealed optimal conditions for the presence of salmonids, but proper conditions for their natural reproduction were found only in the Krąpiel river itself. The substrate structure in the Krępa river, which is $90 \%$ sand, excludes the possibility of reproduction for salmonids and the same is true for the Pęzinka river, in spite of the presence of gravel substrate there, because low water level and slow current do not bode well for potential salmonid reproduction. On the other hand, salmonid reproduction in the Krapiel and in the Pęzinka was confirmed by the presence of breeding nests found in those rivers in 2012, in locations where the main fraction of bottom sediments was sand (http://www.lifeina.zzmiuw. pl/images/pliki/monitoring/2_e_ii_podz_1.pdf).

In summary, it should be stressed that bottom sediment structure has an important effect on the biocenoses of the Krapiel river and its tributaries. Gravel substrate is a good habitat for psephophilous fauna and provides favourable conditions for the presence and reproduction of salmonids.

\section{CONCLUSIONS}

1. According to Polish Standard of 1986 and of 2006, bottom sediments in the Krapiel river and its tributaries can be classified as coarse sediments, with gravel and sandy gravel being the prevailing fractions.

2. According to Wentworth scale used in AngloSaxon countries, bottom sediments in the Krapiel river and its tributaries can be classified as sand, with medium sand and fine sand being the prevailing fractions.

3. Gravel substrate is a good habitat for invertebrate fauna inhabiting that sediment type, with the Insecta as a dominant group.

4. The prevalence of coarse sediments provides favourable conditions for the presence and reproduction of salmonids along some stretches of the Krapiel river and its tributaries.

\section{REFERENCES}

1. Allan D.J., 1998. Ekologia wód płynących. PWN Warszawa.

2. Bis B., Mikulec A., 2013. Przewodnik do oceny stanu ekologicznego rzek na podstawie makroorganizmów bentosowych. Biblioteka monitoringu środowiska, Warszawa.

3. Blott S.J., Pye K., 2001. Gradistat: a grain size distribution and statistics package for the analysis of unconsolidated sediments. Earth Surf. Process. Landforms, 26, 1237-1248

4. Brysiewicz A., Tański A., Bonisławska M., Szulc J., Formicki K., Wesołowski P., 2012. Zasadność budowy tarlisk dla wędrownych ryb łososiowatych w zlewni Iny na tle badań środowiskowych; część II - Rzeka Krąpiel z dopływami. Woda - Środowisko -Obszary wiejskie, Tom 12, Zeszyt 4, 59-76.

5. Czerniawska-Kusza I., Szoszkiewicz K., 2007. Biologiczna i hydromorfologiczna ocena wód płynących na przykładzie rzeki Mała Panew. WIOŚ, Opole

6. Czerniawska-Kusza I., 2001. Zmiany w zespole fauny dennej dolnego biegu Nysy Kłodzkiej pod wpływem czynników abiotycznych i antropogenicznych [Changes in benthic fauna assemblages in the lower course of the Nysa Kłodzka under the influence of anthropogenic abiotic factors]. Opolskie Towarzystwo Przyjaciół Nauk, Zeszyty Przyrodnicze, 35, 72-84.

7. Głazaczow A., 1999. Psammofilne jętki (Ephemeroptera), ginący element fauny polskich rzek. Roczniki Naukowe Pol. Tow. Ochr. Przyr. „Salamandra", 3, 75-86. 
8. http://www.lifeina.zzmiuw.pl/images/pliki/monitoring/2_e_ii_podz_1.pdf - Raport etapowy z realizacji zadania nr $\overline{2}-$ Liczenie gniazd tarłowych, podzadanie nr 1 - ,Badania elementów biologicznych” prowadzonego w ramach działania „Przeprowadzenie oceny stanu zasobów przyrodniczych zlewni rzeki Iny w ramach projektu LIFE+ pn. „Budowa niebieskiego korytarza ekologicznego wzdłuż doliny rzeki Iny i jej dopływów”.

9. Keszka S., Tański A., Raczyński M., Pender R., Furdyna A., Potkański Ł. 2013. Ichtiofauna systemu rzeki Iny, Rocz. Nauk. PZW (Sci. Ann. Pol. Angl. Assoc.), vol. 26, 117-149.

10. Kownacki A., Soszka H., Flaituch T., Kudelska D., 2004. The ecological assessment of river qualityin Poland on the basis of communities of benthic invertebrates. In: Kownacki A., Soszka H., Flaituch T., Kudelska D. (Eds.) River biomonitoring and benthic invertebrate comunnites. Szafer Institute of Botany, Polish Academy osf Sciences Warsaw-Cracov.

11. Kownacki A., Soszka H., 2004. Wytyczne do oceny stanu rzek na podstawie makrobezkręgowców oraz do pobierania prób makrobezkręgowców w jeziorach. WIOŚ Warszawa,

12. Lampart Kałużniacka M., Śliwińska A., 2011. Ocena stanu ekologicznego cieków Jeziora Trzesiecko na podstawie wskaźników biotycznych. Rocznik Ochrona Środowiska, Tom 13, 1069-1080

13. Piechocki A., 1986. Studies on Pisidium species (Bivalvia, Sphaeridae) of the Polish loess area rivers. Proc. 8th Int. Malacol. Congr., Budapest (1983), 187-192.

14. Piechocki A., 1992. Mięczaki wodne (Mollusca aquatica) Roztocza [Freshwater molluscs (Mollusca aquatica) Mites]. Fragm. Faun. 35(17), 285-299.

15. PN- EN ISO 14688-1:2006, Badania geotechniczne. Oznaczanie i klasyfikowanie gruntów. Część 1: Oznaczanie i opis.

16. PN- EN ISO 14688-2:2006, Badania geotechniczne. Oznaczanie i klasyfikowanie gruntów. Część 2: Zasady klasyfikowania.

17. PN-B-02480:1986, Grunty budowlane. Określenia, symbole, podział i opis gruntów.
18. Raczyńska M., Grzeszczyk-Kowalska A., Chojnacki J.C., Raczyński M., 2012a. Impact of Taxonomic Structure and Benthic Fauna Biomass on the Biological Classification of River Waters. Ecological chemistry and engineering A, 19(4-5):421-431, DOI: 10.2428/ecea.2012.19(04)044

19. Raczyńska M., Chojnacki J., Grzeszczyk-Kowalska A., Raczyński M., Kowalczyk S., 2012b. Chruściki Trichoptera jako składnik biocenozy wybranych rzek dorzecza Odry, In: Wawrzyniak W., Zaborowski T. (Eds.) Entouraqe pogranicza. Gorzów Wlkp.-Poznań, IBEN Gorzów Wlkp, 345-360.

20. Raczyńska M., Grzeszczyk-Kowalska A., Chojnacki J.C., Dworczak H., 2010. Influence of substrate on the domination structure of macrozoobenthos in selected streams in the Lower oder River catchment, t.2, 474-481. In: Afanasiewa (Ed.) Analiz i prognozirowanie sistem uprawlenia, Ros. Akad. Nauk. Sankt Petersb. 2.

21. Raczyńska M., Machula S., 2006. Oddziaływanie stawów karpiowych na jakość wód rzeki Krąpiel (Pomorze Zachodnie). Infrastruktura i Ekologia Terenów Wiejskich, 4/2/2006, 141-149.

22. Rybak J., Umińska-Wasiluk B., Wykorzystanie makrobezkręgowców bentosowych do oceny jakości wód powierzchniowych na przykładzie rzeki Piławy, Ochrona Środowiska, 29(2), 55-60

23. Włosik-Bieńczak E., 1992. Małże z rodzin Sphaeridae i Pisidiidae (Mollusca, Bivalvia) w północno-zachodniej Polsce [Mussels from the families Sphaeridae and Pisidiidae (Mollusca, Bivalvia) in northwest Poland]. Lubuski Przegl. Przyr. 3, 3-51.

24. Zieliński P., Górniak A, Bralski M. 2012. Wykorzystanie cech hydromorfologicznych do oceny stanu ekologicznego rzeki miejskiej. Inżynieria Ekologiczna nr 29.

25. Złoczowska I., Wierzchowska E., Robak-Bakierowska A., Jurkiewicz E., Szatkowska-Konon H., 2008. Rozdział V - Ochrona wód. In: Landsberg-Uczciwek M. (Ed.) Raport o stanie środowiska w województwie zachodniopomorskim w latach 2006-2007, Biblioteka Monitoringu Środowiska, Szczecin, 56-60. 